\title{
Problems of Malay Language Education in Patani Southern Thailand
}

\author{
Phaosan Jehwae ${ }^{1}$, Mahamatsakree Manyunu ${ }^{2}$ \\ \{fazdany@hotmail.com ${ }^{1}$, makee4@yahoo.com ${ }^{2}$ \} \\ Fatony University, Thailand ${ }^{1,2}$
}

\begin{abstract}
The problems of Malay language education in Patani, Southern Thailand is experiencing volatility in political developments in Thailand. The Malay language was once the most important language in Patani and was used in various official or unofficial situations. Malay became an important language in the cottage education system in Patani until Malay. Since Patani fell under the Siamese rule then changed the name of Thailand, the Malay language changed to the worst. The Malay language is not the main language in Patani's educational system but is simply a misleading subject in Islamic scholarship that is taught in government schools and becomes one of the mandatory subjects in Patani hut schools. However, the struggle to uphold the education of the Malay language has never been silent. In the late 2000s, which was an era of awakening, the education of the Malay language began to be observed by all groups including the Thai government. The Thai government has provided a wide opportunity for the use of Malay language, such as the use of Malay language in radio and television broadcasting, billboards, arrangement of Malay language courses, provision of Malay language instructors in several universities as well as bilingual school plans have been implemented in three southern Thai provinces.
\end{abstract}

Keywords. Problems Malay Language Patani

\section{Introduction}

The problems of Malay language education in Patani will provide an overview of the importance of the language in their lives. Malay language is the majority language of the population in Patani. Malay became the mother tongue of the Malays in the five provinces of the former Patani sultanate. The Patani Malay race is a minority in Thailand because of the majority of Siamese and Thai-speaking people in Thailand. The Malays are the majority populations of minorities, they are the majority of the population in the five Thai border areas but they are a minority population in Thailand. According to Paitoon (2005: 53), about 75 percent of the population in five southern Thai provinces are Muslims, speak Malay and adhere to Malay customs.

The Malay language and culture in Patani has changed since the Thai government had embarked on the Siamisation policy of all its colonies. The Siamisation policy which obligates the whole Thai people to use Thai in all primary schools in Thai States. Since the Siamisation policy, there was concern over the development of the Malay language in Patani in particular relating to the influence of Thai language. The influence of Thai so strong on the Malay language resulted in the manipulation of skills in the Malay language. Ahmad Fathi (2001: 209) said the position of the Malay language in Patani was getting worse today. The Malay language 
is only used as the language of daily communication, language in religious ceremonies and the medium of instruction in Islamic jurisprudence in cottage schools. Malay is no longer used in official affairs with the government, mass media, signboards, and the use of limited Malay language, which is used only by the Patani Malays.

\section{Hostory Of Patani}

History of Patani from Langkasuka until the Patani Darussalam Country made Malay the official language of the kingdom. The Patani government uses the Malay language as the language of government, the language of education, the language of law, the language of commerce and the language of diplomacy. Historical background of Patani is very closely related to this investigation. During the reign of Patani's loyalty to the Patani occupation era under Siam, the Malay language was always a very important issue. In the history of Patani, the Malay language is not merely an official language or communication language but Malay is recognized as the same as Islam. Patani, Islamic religion and Malay become phenomenon that can not be separated from each other.

Patani Darussalam, located on the east coast of Malaysia's peninsula is neighboring Kelantan, Kedah, Perlis, Perak and north of Siam. Patani's position on the Siamese peninsula is strategically geographically, causing the country to be the focus of foreign traders both from the West and East to stop either to rest or trade. In a very short time, Patani has emerged as an important and economically developed country and politically and politically stable. The basis of good international relations has saved Patani from Siamese and Western colonies, especially Portuguese and Dutch. Patani is believed to be the first Islamic state in Southeast Asia, about the 10th century $\mathrm{AD}$, but recently known as the center of Islamic activity and world trade in the 16th century. The inclusion of Islam in Patani brought Patani more known and stronger politics internationally ( MohdZamberi, 2006: 32).

Prior to the formation of the Patani Malay Islamic kingdom, this kingdom was known as the Langkasuka, an old Malay kingdom in the Malay Peninsula. Langkasuka became the center of high Malay civilization in the archipelago. Various infrastructure development has been developed, the development of Sanskrit-Malay culture and language. The Patani people at that time had not embraced any religion. According to Mohd. Zamberi (2006: 29-30), the Patani people then embraced Hinduism and Buddhism. The people of Langkasuka already have a high civilization and can administer a very large kingdom. Langkasuka has become the center of international trade visited by traders from India, China, Khmer, Java, Bugis, Persia and others.

In 775, the Sriwijaya kingdom succeeded in conquering Nakhon Sri Thamarat and expanding its power to the kingdom of Langkasuka. Sriwijaya Kingdom has spread Buddhism and Malay language in Patani is estimated to be developed by Sriwijaya kingdom (Ahmad Fathi, 2001: 8). Since the name of Langkasuka was slowly lost and in the 14th century, the kingdom of Sriwijaya has suffered a slowdown and slowly losing its colonies (Hasan, 1992: 638). The collapse of the Langkasuka kingdom was accelerated with the spread of Islam in the archipelago from the 10th to the 13th century AD (MohdZamberi, 2006: 53).

Patani's government was established as a new power after the reign of Sriwijaya. The first king in the re-emergence of Patani was known as the King of the Monarch and he was a Buddhist. He was later succeeded by his son King Antira (Ibrahim, 2002: 32). When King Antira ruled, Patani was approached by an outside trader and became the center of advanced commerce so that one day King Antira suffered a difficult illness and no one could treat him 
until a trader from the Middle East to treat him on condition that he recovered the Antira King embracing Islam. It is evident that the trader was cured by King Antira healed and embraced Islam until Patani turned into an Islamic Malay empire (MohdZamberi, 2006: 33).

After the collapse of Malacca and the destruction of its port, Patani port took over the role played by Melaka. Its strategic port position is the route of ships from western and eastern states. Patani is also the center of the spread of Islam in the early Nusantara. Patani became the center of Islamic science has invited students from all over the archipelago to assemble in Patani. Patani also became a defense fortress for the Malay states in the peninsula from the threat of the enemy, especially Siamese. On May 11, 1634, the Siamese armed forces amounted to 60,000 people trying to attack Patani for their colonies. Patani could break the Siamese army and always win in the next battle for five times (MohdZamberi, 2006: 58).

The Patani Malay Sultanate had reached its peak in the reign of Queen-Ratu (1584-1688). At that time Patani has emerged as the most important trading center in the archipelago. Ijzerman, a Dutch merchant (Ibrahim, 2002: 73) states that Patani is the gateway for merchants who want to trade in China and its surroundings. Various types of goods are reported around the port city of Patani. This statement is reinforced by Peter Floris (Ibrahim, 2002: 38, MohdZamberi, 2006: 122-126)) an English traveler who trades in Patani between 1612-1613, writes that Patani has a good relationship with all states in the region South East Asia. Patani's economic strength, coupled with domestic political stability, has made Patani a strong and respected state by neighboring nations including the Siamese government itself. The political influence of Patani has spread to some Malay kingdoms in the Malay peninsula.

The wealthy Patani State has been overtaken by the Siamese until Siam used various means to destroy Patani. But the strength of Patani as a small Malay state did not last long as the enemy always sought the opportunity to destroy and capture Patani. The Treaty of Bangkok in 1909 between Siam and the British has confirmed that Patani was legally a Siamese territory, which in the former (1902) was merely a Siamese state, similar to the states of Perlis, Kedah, Kelantan and Terengganu. With the signing of the Bangkok Treaty of 1909, officially the Malay Sultanate's system of government was abolished and Patani was recognized by the British as a part of the Siamese territory despite the willingness of the Patani Malays. Then the Patani state is divided into five areas such as Pattani, Narathiwat, Yala, Songkla and Setun (NikAnuar: 1994: 22, MohdZamberi, 2006: 139-40).

Since the colonization of Siam against Patani, the position of Malay is no longer the official language of the Malay community in Patani but Malay is still used as a means of communication and teaching of Islam. Confidence in Islam is the same as the Malay language is still adopted by the Patani people to date. Looking at the history of Patani's history, it is possible to show that Patani society, Islam and Malay language links can not be separated from one another.

\section{Ease Of Use}

\subsection{Malay Language Position in Patani, Southern Thai}

The history of Malay education in Patani, South Thai depends on the political atmosphere of the Thai nation. The Malay language in Thailand is a minority language. Since the 15th century the Malay language has become an important language of communication (lingua franca) in Thai. The Thai nation has used Malay language in trade and in diplomacy with other 
countries. BahasaMelayu is the language used in the archipelago since its longing and became the official language in several countries in the archipelago. BahasaMelayu is the official language of Brunei Darussalam, Indonesia, Malaysia and Singapore. In addition to the Malay language became the official language of the country, Malay became the language of communication in several parts of Southeast Asia such as Patani, Moro, Philippines and Timor Laste.

The Malay language in Thai is generally a minority language because only a few places are still Malay. There are some areas around Bangkok that still use Malay in communicating with each other such as Ayuthya, Minburi, Tha'it, Klongneng, TambonBangpo and KloungluangPathomthani (Hasan, 1992: 637). Whereas in Patani, South Thai, especially in the five border areas of Thai, Malay became the majority language (Worawit, 2002: 28).The position of Malay as the majority is the only legacy of the most valuable heritage of the Malay community. The Malay language in Patani is the language of majority. Malay plays a very important role in Patani. Malay is the main tool for expressing thoughts, feelings, emotions, needs and others. Malay is a communication tool in daily life and this language is spoken extensively by all classes. The Malay language is spoken by ordinary people, government officials, private officials and traders who are Malays and non-Malays.

The function of Malay language in the field of education is as the medium of instruction in the teaching of Islam and Malay. Teachers and religious teachers use books or books in Standard Malay. The Malay language was also used as a Christian missionary media by Western missionaries to spread Christianity in Patani. According to Ahmad Omar (2002: 39) there are 400 cottage schools that use the Malay language as the medium of religion and Malay language in Patani. The private schools belong to the locals, they use two systems in the teaching process. They use the Malay language in teaching religious subjects and Malay language. While in the presentation, they use Patani Malay language and there are several schools using mixed language between Patani Malay and Thai. While in academic learning, they use 100 percent Thai-language books and use Malay in describing them.

The second function of the Malay language in Patani is as a political language. Since the political crisis in Patani, the Thai government has seen how important the position and role of Malay language is for the Patani community. BahasaMelayu can be a vehicle of peace in Patani. Hence, various mass media related Thai government policies in Malay, both print and electronic media in Malay.

\subsection{Problems of Malay Language Education in Patani, Southern Thailand}

Problems of Malay language education in Patani, South Thai is not spared from the role of cottage schools. The cottage school plays a very important role in defending the sovereignty of the Malay language. BahasaMelayu is used as the main language of religion. Before it was known by the name of a private Islamic religious school (cottage school), there was a schooling institution known as 'cottage'. Pondok was an important institution in the development of education, Malay language, the spread of Islam and the Malay cultural center (Lazim, 2007: 168). The cottage institution emerged in line with the emergence of Patani as a center of development and Islamic activities in Southeast Asia. The cottage is thought to have originated from Patani and then students graduating from Patani open houses in different parts of the country (Ismail Hussein, 1989: 771-778).

From the 17th century AD to the early 20th century AD, Patani is the world's leading mission and education center. The cottage fame in Patani invites students from various states to come to Patani to pursue knowledge so that it becomes the centerpiece of Islamic Malay script. 
The evidence of Patani as the famous Malay correspondence center can be seen by emerging world scholars, such as Syed Daud Al-Fathoni, Syed ZainalAbidin Al-Fathoni, Syed Ahmad Al-Fathoni. Syed Daud Al-Fathoni has produced 58 books in Arabic and Malay. Some of the books of Syed Daud are still studied in some cottage schools both in Patani and in Malaysia. The books are written in Arabic and Malay so that the position of Malay is a very important medium in delivering its description.

The statement, reinforced by Mohd. Zamberi (1994: 243) The Malay language in Patani has become the language of knowledge, and successfully placed Patani as a center of civilization of Islamic Malay literature through the creation of religious works by scholars. The use of such religious books as a reference material is so widespread that it reaches the Middle East and North Africa. Students who come to study and study in Patani come from various parts of the world such as Sri Lanka, Burma, Kombodia, Vietnam and the Malay states of the archipelago. Students who are not from the Malay states, they must learn Malay as a directive in the Malay language system. (Abdullatif, 1987: 266).

After Patani was colonized by Siam, the cottage institution also fell. The cottage institution as the center of education and da'wah is experiencing decline and sluggishness. The sting and slump caused the huts to no longer be the center of education and well-known da'wah. In the 1960s there were 1000 cottage schools throughout Patani. The Thai government began to intervene in the education and religious affairs of the Patani community so that the government forced Thai to teach in all cottage schools causing many cottage schools to be closed and dismissed (UthaiDulyakasem, 1981: 63). The Thai government began to suspect the cottages so many cottages were closed. The remaining lodges are required by the government to register under the Thai government. There are about 400 Islamic religious private schools in five southern Thai provinces (Ahmad Omar, 2002: 39). The government divided the cottage into two institutions. First, the cottage receiving assistance from the Thai empire, is known as a cottage school. Secondly, the cottage is only registered as a cottage institution.

The cottages are divided into two systems. First, the hut still defends the old system, teaches the yellow book in Arabic and Malay. They study at the mosque or mosque and live in small huts. Now this cottage system has begun to disappear in Patani earth and only a few are still active. Second, it is a hut in the form of a private Islamic religious school (cottage school). This cottage is a change from the old cottage system to the school system. BahasaMelayu is an important delivery tool in the cottage education system and religious ceremonies at Patani (JiraphanDema, 2008: 23)

The cottage is in the form of this school, teaching and learning in two forms, religion and academic. This cottage receives full assistance from the Thai government as long as the cottage has to teach academics in Thai. Religious divisions, this hut is still using Malay as the medium of instruction and there are some hut schools that teach religion in Thai on the grounds that many students do not understand Malay. However the hut in the form of the old or in the form of school is still in the role of defending the Malay language in Patani.

The Thai government's policy of Malay has always changed in the current political stream. In the early days of Patani with Siam so far, Malay language has always been a hot issue and debate. In the $1940 \mathrm{~s}$, PhibunSongkram as prime minister at that time, had stirred up the spirit of nationalism by implementing the Ratthaniyom Thai policy. The grounds introduced by Phibun are as follows.

- Prohibit educational institutions to teach in Malay because the language is not the official language of the country.

- Close the Islamic religious institutions that teach in Malay.

- Prohibit Malays to speak Malay. 
- Forcing the Malays to convert the Malay names into Siamese names.

- Convert the names of villages in Malay into Siamese language throughout the Malay territory.

- To work hard for Malays who speak Malay when dealing in government offices.

- Prohibit Malays to wear Malay clothes.

As a result of these policies, the Malays were restless and worried over the destruction of Malay identity and religious freedom. They feel challenged because they are forced to practice western and Siamese cults that are very contrary to Malay culture and Islamic teachings. The elderly feel very nervous because they are forbidden to wear turban, skull or wrapped around the semicircle in the head, which should be replaced by the use of a hat. Malay has become an official language since Langkasuka, was banned and prohibited to be used in government offices and had to use the very foreign language of the Patani people. All high positions are not given to the Malays and the activities of Islam are restricted because Buddhism is the official religion of Siam. His clash with the closure of the Islamic Religious Council throughout the Malay Patani region (NikAnuar and MohdZamberi, 2006: 106).

The Siamisation policy was strongly opposed by Patani residents led by Haji Sulong who was known for seven demands (ChalermkiatKhuntongphet, 2004: 23, NikAnuar and MohdZamberi, 2001: 109). Claims of seven cases that led to Haji Sulong accused of being rebels and killed by the mystery are as follows.

- Demand the government to recognize the four southern provinces of Patani, Yala, Narathiwat and Satun as a Malay territory, and to appoint government representatives from the population born in these four provinces and have full administrative authority.

- Must be $80 \%$ of government officials serving in these four regions are Muslims.

- Malay and Siamese language shall be the official language.

- BahasaMelayu should be used as a medium of instruction in primary schools.

- Islamic law shall be recognized and enforced in the Syariah Court.

- All proceeds and income derived from these four territories shall be used in these territories only.

- Establish a body of full authority to manage all the affairs of Muslims who are under the responsibility of the Head of State.

The above claim does not require an independent state but to improve the fate of the very oppressed Malays at that time. In the beginning rumors say that some of the things Patani demanded would result in the approval of the Thai authorities unless the first claim to touch the Thai constitution was rejected. The political situation in the Thai state changed suddenly when a coup came in Bangkok in 1947M, after which Phibun returned to power. On 16 January 1948 M, Haji Sulong and colleagues were arrested and killed in mysterious manner (MohdZamberi, 2006: 111). Although efforts to defend the identity of the Malays have been unsuccessful but the consequences of the demands have changed the political policy in the Thai nation especially in relation to the Malay language.

In the 1950s the Thai government again allowed the teaching of Malay language to be taught in government-owned schools by bringing the Malay language teachers from Singapore and Malaysia. But later, Malay language teaching was no longer taught in government schools, so Malay language teachers had to teach Malay in their respective homes. In the 1960 's, the kingdom began to intervene in the cottage school business in Patani. The government started providing financial assistance to the registered cottage schools but 
provided the subjects of Siam / Thai in the curriculum school curriculum. The government seeks to undermine the Malay language position, before all academic subjects use the whole Malay language.

In $1968 \mathrm{M}$, the Thai government announced that all huts received assistance would be reduced by the use of Malay language in academic subjects and replaced with Thai language. In $1971 \mathrm{M}$, the government required all cottage schools to register at the Thai Ministry of Education, if the cottage school did not register the government would take decisive action by closing the school forcibly. The position of Malay as the medium of instruction in all academic subjects has been lost and replaced by Thai. Malay live as one of the subjects of religion and as an introductory language of religious subjects. In the 1980s, Malay subjects were incorporated into several government schools with Islamic religious subjects but only two hours a week (Worawit, 1998: 187).

After the Malay language was not taught in government-owned primary school, the Patani community opened Malay schools that taught religion and Malay in surau and mosque. The Malay school is known as Kindergarten. Furthermore, Malay language is taught in Kindergarten schools as the primary basis for religious instruction and provides textbooks written by Jawi and Rumi as a medium for teaching and learning at kindergartens. While primary schools or elementary schools in southern Thailand, generally comprise government schools. Every Thai citizen, including Malay children, is required to attend basic education at these schools within the span of six years. Even now the education level must be extended to the middle level, which is nine years. For Malay children, they generally follow the basic education level at government-owned primary schools then pursue secondary education at a private Islamic religious school. Thus, children in southern Thailand have the opportunity to learn religion and Malay as an extension of religious education and Malay language.

\section{Conclusion}

Patani has once been an independent State and has made Malay the official language / official language in all its life affairs. After the British agreement in 1909, officially Patani was under Siam (later renamed Thailand / Thailand). The position of Malay as the main language of the Patani Malays in their lives, especially in the field of education, led the Thai government to suspect the position of the Malay language. The history of Malay language education in Patani depends on the political temperature of the Thai government. Various Thai Siamese policy of Thai residents by PhibunSongkram have been implemented, but the Malays are still working to provide alternative rescuers to this problem so that Malay and Islamic identity will be preserved. For the Thai government, they are also trying to eliminate these replacement schools by providing some religious instruction in national schools. Teachers who teach also are not from good graduate in religion and Malay language. The cottage and Tadika schools play an important role in preserving the Malay language in Patani. Since the security crisis in Southern Thailand in 2005, the Thai empire began to emphasize the identity of the Patani Malay identity, especially in religious and language fields. The government began to open up religious and Malay subjects in government-owned schools. The government has taken religious and Malay language teachers into government-owned schools. The Thai government has provided a wide opportunity for the use of Malay language, such as the use of Malay language in radio and television broadcasting, billboards, arrangement of Malay 
language courses, provision of Malay language instructors in several universities as well as bilingual school plans have been implemented in three southern Thai provinces.

\section{References}

[1] Ahmad Fathi (2001). PengantarsejarahFathoni. Kota Bharu: PustakaAman Press Sdn. Bhd.

[2] Ahmad Omar (2002).Politik Thai danmasyarakat Islam di selatan Thailand. AlorSetar: Pustaka Darussalam.

[3] ChalermkiatKhuntongphet (2004). Penentangan Haji Sulong Abdul QadirterhadapDasarKerajaan di Empat Wilayah Selatan Thai di antaratahun 1939-1954. Bangkok:Matichon book.

[4] HasanMadmarn( 2001). Pondokdan Madrasah di Patani. Bangi: UniversitiKebangsaan Malaysia.

[5] Ibrahim Syukri (2002). SejarahKerajaanMelayuPatani. Bangi: Penerbit UKM

[6] JiraphanDema (2008) KerikulamdanPengurusPendidikan di dalamWilayah Selatan Thailand. Kertaskerjadalam seminar AkademikTajukMelayudengan Rat Thai dam pefektifSejarahdanTammaduldengan Cara MembinaKeadilan, Universiti Princess of Songkhla.

[7] Mohd. Zamberi A. Malek (1994). PatanidalamTamadunMelayu. Selangor: DewanBahasadanPustaka.

[8] Mohd. Zamberi A. Malek (2006). PensejarahanPatani. KL: Penerbit UM.

[9] Muhammad LazimLawi (2005).SejarahdanPerkembangan Agama AnutiMasyarakatMelayuPatani.Kolej Islam Jala: PusatKebudayaan Islam.

[10] NikAnuarNik Mahmud (1999). SejarahPerjuanganMelayuPatani. Bangi: Penerbit UKM.

[11] Paitoon M. Chaiyanara (2005). "Transmorfofonologisasisuprafiks: dialekPatanimerentasizaman". JurnalBahasa 5(1).

[12] Paitoon M. Chayanara (1990). Kata-kata Sanskrit DalamBahasaMelayudanBahasa Thai: SatuKajianPerbandingan Dari SegiFonologi. Tesis Ph.D.JabatanPengajianMelayu, Universiti Malaya.

[13] RuslanUthai (2008). BahasadalamRattai :TammaduldanKeadilan, KertasKerja Seminar "Melayudengan Rat Thai danpefektifSejarahdanTammaduldengan Cara MembinaKeadilan", Universiti Princess OF Songkhla.

[14] WorawitBaru (1990). PengaruhBahasa Thai KeAtasDialekMelayuPatani: KajianKesSosialinguistik Di Wilayah Pattani. TesisSarjana. JabatanPengajianMelayu, Universiti Malaya.

[15] WorawitBaru (1999). DasarKerajaandanKesannyaTerhadapBahasaMelayu di Negara Thai. Tesis Ph.D. Universiti Malaya. 